\title{
Single-Crystal Tungsten Oxide Nanosheets: Photochemical Water Oxidation in the Quantum Confinement Regime
}

\author{
Mollie R. Waller, ${ }^{\dagger}$ Troy K. Townsend, $^{\dagger}$ Jing Zhao, ${ }^{\dagger}$ Erwin M. Sabio, ${ }^{\dagger}$ Rachel L. Chamousis, ${ }^{\dagger}$ \\ Nigel D. Browning, ${ }^{\ddagger}$ and Frank E. Osterloh* ${ }^{* \dagger}$
}

${ }^{\dagger}$ Department of Chemistry and ${ }^{\ddagger}$ Department of Chemical Engineering and Materials Science, Department of Molecular and Cellular Biology, University of California, Davis, One Shields Avenue, Davis, California 95616, United States

\begin{abstract}
Here we investigate the structure, photophysics, and photocatalytic water splitting properties of single-crystalline $\mathrm{WO}_{3}$ nanosheets $(0.75 \mathrm{~nm} \times 90 \pm 38 \mathrm{~nm})$, obtained by exfoliation from $\mathrm{Bi}_{2} \mathrm{~W}_{2} \mathrm{O}_{9}$. Upon delamination, the nanosheets undergo a structural change from tetragonal symmetry in the parent material to monoclinic, as confirmed by powder $\mathrm{X}$-ray diffraction and electron microscopy. Diffuse reflectance optical spectra show band gap energies consistent with quantum confinement in nano- $\mathrm{WO}_{3}\left(E_{\mathrm{G}}=2.88 \mathrm{eV}\right)$ and $\mathrm{Bi}_{2} \mathrm{~W}_{2} \mathrm{O}_{9}$ $\left(E_{\mathrm{G}}=2.81 \mathrm{eV}\right)$, relative to bulk $\mathrm{WO}_{3}\left(E_{\mathrm{G}}=2.68 \mathrm{eV}\right)$. Surface photovoltage measurements on nano- $\mathrm{WO}_{3}$ films on a $\mathrm{F}: \mathrm{SnO}_{2}$ substrate demonstrate photochemical carrier formation under band gap excitation and irreversible trapping of holes. Photochemical oxygen formation is observed with $50 \mathrm{mg}$ of the material in aqueous $\mathrm{AgNO}_{3}$ and $\left(\mathrm{NH}_{4}\right)_{2} \mathrm{Ce}\left(\mathrm{NO}_{3}\right)_{6}$ solutions under

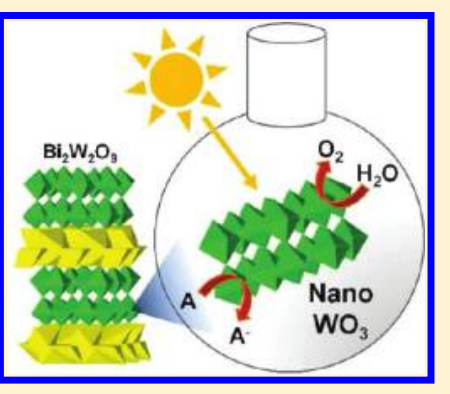
full spectrum $(>250 \mathrm{~nm})$ or visible only $(>400 \mathrm{~nm})$ irradiation. The highest initial $\mathrm{O}_{2}$ evolution rates $\left(69.7 \mu \mathrm{mol} \mathrm{h}{ }^{-1}\right.$ for bulk and $35.5 \mu \mathrm{mol} \mathrm{h}^{-1}$ for nano- $\left.\mathrm{WO}_{3}\right)$ are observed under $>250 \mathrm{~nm}$ illumination in the presence of $8.3 \mathrm{mM} \mathrm{AgNO}(\mathrm{aq})$. Quantum efficiencies (at $375 \mathrm{~nm}$ ) reach $1.43 \%$ and $1.55 \%$ for bulk and nano- $\mathrm{WO}_{3}$, respectively. Electrochemical measurements reveal large water oxidation overpotentials $(0.96 \mathrm{~V})$ for both nano- and bulk- $\mathrm{WO}_{3}$. On the basis of photo-onset measurements, the conduction band edges in nano-/bulk- $\mathrm{WO}_{3}$ are at $+0.11 /+0.23 \mathrm{~V}$, respectively. Overall, the data show that the photoelectrochemical water oxidation ability of $\mathrm{WO}_{3}$ is maintained in $0.75 \mathrm{~nm}$ nanocrystal $\mathrm{WO}_{3}$ sheets, although more energetic photons are required because of the extended band gap.
\end{abstract}

KEYWORDS: water oxidation, water splitting, photocatalysis, catalysis, $\mathrm{WO}_{3}$, tungsten oxide, nanosheet, nanocrystal, quantum confinement, solar energy conversion

\section{INTRODUCTION}

Tungsten trioxide crystallizes in the $\mathrm{ReO}_{3}$ structure type and is an n-type semiconductor with a $2.7 \mathrm{eV}$ band gap. Since the early works by Hodes and separately by Bard, $\mathrm{WO}_{3}$ has been considered as a promising photoanode material for water oxidation, either as part of a photoelectrochemical cell, ${ }^{1,2}$ or as suspended powder in the presence of a chemical bias. ${ }^{3}$ Turner recently demonstrated a Tandem cell for overall water splitting that used a $\mathrm{WO}_{3}$ photoanode in combination with a $\mathrm{GaInP}_{2}$ photoanode. ${ }^{4}$ Tandem systems based on suspended $\mathrm{WO}_{3}$ particles were also developed by Kudo ${ }^{5,6}$ and by Domen. ${ }^{7-10}$ Under acidic conditions, $\mathrm{WO}_{3}$ generally shows good stability, but photocurrents and quantum yields are low in comparison with $\mathrm{TiO}_{2}{ }^{1}$ These issues could potentially be addressed by nanoscaling the material, which can reduce kinetic charge transfer limitations and increase the thermodynamic driving force via a quantum size effect. ${ }^{11,12}$ For example, enhanced photocatalytic benzene degradation by $1.4 \mathrm{~nm} \mathrm{WO}_{3}$ nanocrystals was recently reported by Tanaka. ${ }^{13}$

Schaak et al. recently showed that single-crystalline, subnanometer thin $\mathrm{WO}_{3}$ nanosheets can be obtained from the layered compound $\mathrm{Bi}_{2} \mathrm{~W}_{2} \mathrm{O}_{9}$. This material consists of $\mathrm{W}_{2} \mathrm{O}_{7}\left({ }^{2-}\right)$ sheets, which are held together by $\mathrm{Bi}_{2} \mathrm{O}_{2}{ }^{2+}$ layers (Figure 1). When $\mathrm{Bi}_{2} \mathrm{~W}_{2} \mathrm{O}_{9}$ is treated with $6 \mathrm{M} \mathrm{HCl}$ at room temperature, selective etching of $\mathrm{Bi}_{2} \mathrm{O}_{2}{ }^{2+}$ layers occurs, and the $\mathrm{WO}_{3}$ layers

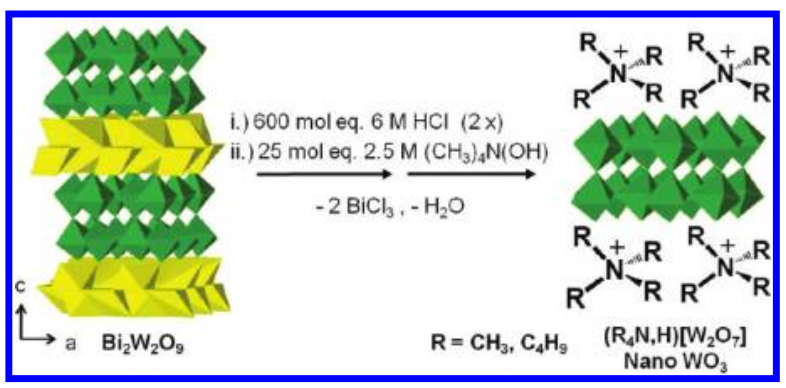

Figure 1. Conversion of $\mathrm{Bi}_{2} \mathrm{~W}_{2} \mathrm{O}_{9}$ to give $\left(\mathrm{R}_{4} \mathrm{~N}, \mathrm{H}\right)\left[\mathrm{W}_{2} \mathrm{O}_{7}\right]$ nanosheets (nano- $\mathrm{WO}_{3}$ ) using a method adapted from Schaak et al. ${ }^{14}$

can be stabilized in the presence of tetramethylammonium surfactant. ${ }^{14}$ The resulting nanosheets (described as nano- $\mathrm{WO}_{3}$ in the following) have the formal composition $\mathrm{H}_{2} \mathrm{~W}_{2} \mathrm{O}_{7}$. Like in the parent compound, the $\mathrm{WO}_{6}$ units are stacked in two levels, giving the sheets a thickness of only $0.75 \mathrm{~nm}$, based on crystallography. Here we report for the first time on the optical, photophysical, electrochemical and photochemical water oxidation properties of the $\mathrm{WO}_{3}$ nanosheets and contrast them with

Received: November 3, 2011

Revised: December 17, 2011

Published: February 16, 2012 
bulk- $\mathrm{WO}_{3}$. We find that nano- $\mathrm{WO}_{3}$ is similar to bulk- $\mathrm{WO}_{3}$, except for an extended band gap that results from quantum confinement. These results demonstrate that the basic photochemical water oxidation functionality of $\mathrm{WO}_{3}$ does not require an extended lattice. It also demonstrates nano- $\mathrm{WO}_{3}$ could be used as functional replacement for $\mathrm{WO}_{3}$, for example in the form of ultrathin films.

\section{EXPERIMENTAL SECTION}

Materials. $\mathrm{Bi}_{2} \mathrm{O}_{3}$ (99.9999\%), $\mathrm{WO}_{3}$ (99+\%), tetramethylammonium hydroxide (TMA $(\mathrm{OH}), 25$ wt \% in water), tetrabutylammonium hydroxide (TBA $(\mathrm{OH}), 40 \mathrm{wt} \%$ in water) and ammonium cerium(IV) nitrate $\left(\left(\mathrm{NH}_{4}\right)_{2} \mathrm{Ce}\left(\mathrm{NO}_{3}\right)_{6}\right)$, 99.5\%) were obtained from Acros Organics and used as received. Hydrochloric acid and $\mathrm{AgNO}_{3}$ were obtained from Fischer Scientific and concentrated $\mathrm{H}_{2} \mathrm{SO}_{4}$ (95-98\%) was received from Sigma-Aldrich. Water was purified by a Nanopure II system to a resistivity of $>18 \mathrm{M} \Omega \mathrm{cm}$.

$\mathrm{WO}_{3}$ Nanosheets. (adapted from Schaak et al). ${ }^{14}$ Stoichiometric amounts of $\mathrm{Bi}_{2} \mathrm{O}_{3}(5.06 \mathrm{~g})$ and $\mathrm{WO}_{3}(4.98 \mathrm{~g})$ were combined and ground to a fine powder with a mortar and pestle. The powder was pressed into pellets and calcined at $800{ }^{\circ} \mathrm{C}$ for $16 \mathrm{~h}$. The resulting yellow solid $\left(\mathrm{Bi}_{2} \mathrm{~W}_{2} \mathrm{O}_{9}, 19.73 \mathrm{~g}\right)$ was again ground to a fine powder and $6.50 \mathrm{~g}$ suspended in $710 \mathrm{~mL}$ of $6 \mathrm{M} \mathrm{HCl}$ (600 mol excess) at RT with stirring. After three days the solid was centrifuged at $3700 \mathrm{rpm}$ for five minutes and the acidic supernatant discarded. The solid was suspended in fresh acid, stirred for three more days, centrifuged off, and washed five times with water before it was dried at $90{ }^{\circ} \mathrm{C}$ in an oven overnight to give $3.23 \mathrm{~g}$ of yellow solid; $3.19 \mathrm{~g}$ of this material $\left(\mathrm{H}_{2} \mathrm{~W}_{2} \mathrm{O}_{7}\right)$ was suspended in $60.57 \mathrm{~g}$ of the TMA $(\mathrm{OH})$ solution ( $25 \mathrm{~mol}$ excess) and stirred at room temperature for 21 days. The exfoliated tungstate (nano- $\mathrm{WO}_{3}$ ) was separated by centrifugation. The solid was then washed with water to $\mathrm{pH} \sim 6$, and dispersed in water for further work up.

Work Up. Dilute TBA $(\mathrm{OH})(\mathrm{aq})(0.5 \mathrm{wt} \%)$ was added dropwise to $\mathrm{pH} \sim 9$ and the solution (approximately $1.5 \mathrm{~g}$ material in $50 \mathrm{~mL}$ water) was sonicated for $15 \mathrm{~min}$ (steps $1 \mathrm{i}$ and lii in Figure 2). The suspension

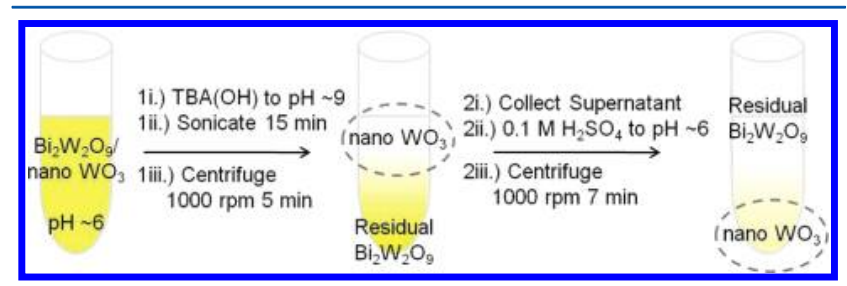

Figure 2. Separation of nano- $\mathrm{WO}_{3}$ from residual $\mathrm{Bi}_{2} \mathrm{~W}_{2} \mathrm{O}_{9}$ material and side products. The final precipitate is suspended in $0.5 \mathrm{wt} \%$ $\mathrm{TBA}(\mathrm{OH})$ for further studies.

was then centrifuged at $1000 \mathrm{rpm}$ for $5 \mathrm{~min}$ and the cloudy, white supernatant collected (steps 1iii and $2 \mathrm{i}$ ). The yellow precipitate was discarded. To the supernatant was added dropwise dilute $\mathrm{H}_{2} \mathrm{SO}_{4(\mathrm{aq})}$ $(0.1 \mathrm{M})$, with stirring, to $\mathrm{pH} \sim 6$ (step $2 \mathrm{ii})$. This solution was immediately centrifuged at $1000 \mathrm{rpm}$ for $7 \mathrm{~min}$ (step 2iii). The slightly cloudy supernatant was discarded and the white precipitate, well exfoliated tungstate nanosheets (nano- $\mathrm{WO}_{3}$ ), was dispersed in $0.5 \mathrm{vol} \%$ $\mathrm{TBA}(\mathrm{OH})(\mathrm{aq})$ for storage. A final product mass of approximately $70 \mathrm{mg}$ represents an overall yield for the process of approximately $4.5 \%$.

Photocatalytic $\mathrm{O}_{2}$ Evolution. Irradiation experiments were performed using a $300 \mathrm{~W}$ Xe lamp, equipped with a water IR filter and with a $400 \mathrm{~nm}$ long-pass filter when necessary. The power received at the flask was $\sim 390 \mathrm{~mW} \mathrm{~cm}^{-2}$ without and $\sim 315 \mathrm{~mW} \mathrm{~cm}^{-2}$ with the long-pass filter. Fifty milligrams of the catalyst was suspended in $50 \mathrm{~mL}$ of an aqueous solution of the sacrificial electron acceptor (either $\mathrm{AgNO}_{3}$ or $\left(\mathrm{NH}_{4}\right)_{2} \mathrm{Ce}\left(\mathrm{NO}_{3}\right)_{6}$ at variable concentration, see Table 1) in a $50 \mathrm{~mL}$ quartz flask. After being evacuated and purged with argon three times, the stirred solution was irradiated for $5 \mathrm{~h}$ with periodic tests of the gas composition. A Varian gas chromatograph with a Supelco molecular 60/80 sieve 5A column and thermal conductivity detector (TCD) with argon as a carrier gas was used for analysis. For quantum efficiency determinations a $375 \mathrm{~nm}$ LED (Roithner Lasertechnik) was used for irradiation of $10 \mathrm{mg}$ of the catalyst in $50 \mathrm{~mL}$ of $2.1 \mathrm{mM}$ aqueous $\mathrm{AgNO}_{3}$. For the nano- $\mathrm{WO}_{3}$ quantum efficiency determination the flux was $2.28 \times 10^{-7} \mathrm{~mol}_{\text {photons s}}{ }^{-1}$, based on the measured power $\left(5.40 \mathrm{~mW} \mathrm{~cm}^{-2}\right)$ of the LED using a GaAsP detector. For the bulk- $\mathrm{WO}_{3}$ quantum efficiency determination the flux was $1.63 \times 10^{-7}$ mol photons $\mathrm{s}^{-1}$, based on a

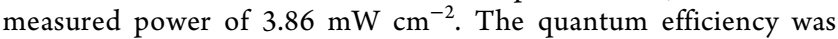
calculated assuming that four photons are necessary for one molecule of $\mathrm{O}_{2}$.

Electrochemistry. Electrochemical measurements were performed using a three-electrode cell equipped with a Pt counter electrode and SCE reference electrode. A fluorine-doped tin oxide (FTO) coated glass electrode $\left(1.0 \mathrm{~cm}^{2}\right.$ exposed area) covered by the $\mathrm{WO}_{3}$ samples served as the working electrode. Films of bulk- $\mathrm{WO}_{3}$ in ethanol and nano- $\mathrm{WO}_{3}$ in water were fabricated by drop-coating the suspensions and drying in air. The electrolyte (aqueous $0.1 \mathrm{M} \mathrm{H}_{2} \mathrm{SO}_{4}$ at $\mathrm{pH} 1$ ) was degassed with nitrogen for ten minutes prior to each measurement. The potential of the $\left[\mathrm{Fe}(\mathrm{CN})_{6}\right]^{3-/ 4-}$ redox couple $(+0.36 \mathrm{~V}$ vs $\mathrm{NHE})$ was used to calibrate the system. Potentials were generated and currents observed with a Gamry Reference 600 potentiostat controlled by a PC. The water oxidation potential was measured by applying anodic scans $(10 \mathrm{mV} / \mathrm{s})$. Photocurrent onset potentials were determined by applying cathodic scans $(10 \mathrm{mV} / \mathrm{s})$ under chopped light. Illumination was provided by a $300 \mathrm{~W}$ Xe arc lamp, equipped with a water filter, using a $\mathrm{SiO}_{2}$ fiber optics cable that delivered $120 \pm$ $20 \mathrm{~mW} / \mathrm{cm}^{2}$ at the electrode, as measured with a GaAsP photodetector. Surface photovoltage measurements were conducted under vacuum $\left(2 \times 10^{-4} \mathrm{mBar}\right)$ on nano- $\mathrm{WO}_{3}$ films on $\mathrm{F}: \mathrm{SnO}_{2}$ (FTO) substrates. A gold Kelvin probe (Delta PHI Besocke) served as the reference electrode. Samples were illuminated with monochromatic light from a $150 \mathrm{~W}$ Xe-lamp filtered through a Oriel Cornerstone 130 monochromator $\left(1-10 \mathrm{~mW} \mathrm{~cm} \mathrm{~cm}^{-2}\right)$.

Other Measurements. Diffuse reflectance UV-vis spectra were collected using an Ocean Optics DH2000 light source and HR2000 CG-UV-NIR spectrometer. Transmission electron microscopy (TEM) was performed using a Philips CM120 transmission electron microscope and a Gatan MegaScan digital camera. Bright field high resolution transmission electron microscopy (BF-HR-TEM) images were taken using a JEOL 2500SE $200 \mathrm{kV}$ TEM. Z-contrast high angle annular dark field scanning TEM (HAADF-STEM) images were taken using a JEOL 2100F STEM with $200 \mathrm{kV}$ field-emission gun and a spherical aberration corrector.

\section{RESULTS AND DISCUSSION}

The addition of tetrabutylammonium hydroxide to the suspension of $\mathrm{WO}_{3}$ nanosheets during workup (Figure 2) improves product separation and provides access to pure $\mathrm{WO}_{3}$ nanosheets on the gram scale, although at low yield ( $4.5 \%$ based on $\mathrm{Bi}_{2} \mathrm{~W}_{2} \mathrm{O}_{9}$ ). According to TEM (Figure 3A), these sheets are fully exfoliated and possess an average edge length of $90( \pm 38)$ $\mathrm{nm}$. The homogeneous thickness of these sheets $(0.75 \mathrm{~nm}$, from unit cell parameters) is supported by the uniform contrast among separate particles. HAADF-STEM (Figure 3B) confirms the crystalline structure of these sheets. Interestingly, the angle between rows $\left(97^{\circ}\right)$ and their spacing $(0.37$ and $0.38 \mathrm{~nm})$ is consistent with the (001) plane of the monoclinic $\mathrm{WO}_{3}$ lattice with unit cell parameters $a=7.297 \AA, b=7.539 \AA, c=7.688 \AA$, and $\beta=90.85^{\circ}$. ${ }^{15}$ The structure of the $\mathrm{Bi}_{2} \mathrm{~W}_{2} \mathrm{O}_{9}$ parent material (Figure 1), on the other hand, consists of WO layers (Figure 3C) with tetragonal symmetry. This is confirmed by the $90^{\circ}$ angle between rows and their spacing $(0.27$ and $0.30 \mathrm{~nm})$, which is consistent with the $(10 \overline{3})$ plane in orthorhombic $\mathrm{Bi}_{2} \mathrm{~W}_{2} \mathrm{O}_{9}$, that is observed with HR-TEM (Figure 3D). 
Table 1. Oxygen Evolution Data For Bulk- $\mathrm{WO}_{3}$ and Nano- $\mathrm{WO}_{3}$

\begin{tabular}{|c|c|c|c|c|c|c|}
\hline sample & conditions & $\begin{array}{l}\text { initial/final } \\
\mathrm{pH}\end{array}$ & $\begin{array}{c}\text { total } \mathrm{O}_{2} \\
\text { generated } \\
(\mu \mathrm{mol})\end{array}$ & $\begin{array}{l}\mathrm{O}_{2} \text { generation rate, } \\
1 \text { st hour }(\mu \mathrm{mol} / \mathrm{h})\end{array}$ & $\begin{array}{l}\text { quantum efficiency } \\
(\%) \text { at } 375 \mathrm{~nm}\end{array}$ & $\begin{array}{l}\text { turnover no. }(\mu \mathrm{mol} \\
\left.\mathrm{O}_{2} / \mu \text { mol tungsten }\right)\end{array}$ \\
\hline $\mathrm{Bi}_{2} \mathrm{~W}_{2} \mathrm{O}_{9}{ }^{a}$ & $\begin{array}{l}0.05 \mathrm{M} \mathrm{Ag}^{+} / \mathrm{UV}(450 \mathrm{~W} \mathrm{Hg} \text { lamp) } \\
\text { from Kudo et al. }{ }^{21}\end{array}$ & & & 281 & & \\
\hline bulk- $\mathrm{WO}_{3}{ }^{b}$ & $8.3 \mathrm{mM} \mathrm{Ag}^{+} />250 \mathrm{~nm}$ & $4.96 / 2.22$ & 133.9 & 69.7 & & 0.621 \\
\hline nano- $\mathrm{WO}_{3}{ }^{b}$ & $8.3 \mathrm{mM} \mathrm{Ag}^{+} />250 \mathrm{~nm}$ & $6.48 / 2.61$ & 61.2 & 35.5 & & 0.284 \\
\hline bulk-WO${ }_{3}^{b}$ & $8.3 \mathrm{mM} \mathrm{Ag}^{+} />400 \mathrm{~nm}$ & $4.87 / 2.21$ & 117.0 & 39.8 & & 0.543 \\
\hline nano- $\mathrm{WO}_{3}{ }^{b}$ & $8.3 \mathrm{mM} \mathrm{Ag}^{+} />400 \mathrm{~nm}$ & $6.50 / 2.71$ & 31.8 & 5.2 & & 0.147 \\
\hline bulk- $\mathrm{WO}_{3}^{b}$ & $2.1 \mathrm{mM} \mathrm{Ce}^{4+} />400 \mathrm{~nm}$ & $2.28 / 2.31$ & 27.6 & 8.4 & & 0.128 \\
\hline nano- $\mathrm{WO}_{3}{ }^{b}$ & $2.1 \mathrm{mM} \mathrm{Ce}^{4+} />400 \mathrm{~nm}$ & $2.85 / 2.90$ & 16.1 & 5.9 & & 0.075 \\
\hline bulk- $\mathrm{WO}_{3}{ }^{c}$ & $1.7 \mathrm{mM} \mathrm{Ag}^{+} / 375 \mathrm{~nm}$ & $6.35 / 3.71$ & 10.5 & 2.5 & $1.43^{d}$ & 0.243 \\
\hline nano- $\mathrm{WO}_{3}{ }^{\mathrm{c}}$ & $1.7 \mathrm{mM} \mathrm{Ag}^{+} / 375 \mathrm{~nm}$ & $6.51 / 3.37$ & 10.7 & 3.2 & $1.55^{d}$ & 0.248 \\
\hline
\end{tabular}

${ }^{a} 1$ g. ${ }^{b} 50 \mathrm{mg} .{ }^{c} 10 \mathrm{mg}$. ${ }^{d}$ Quantum efficiencies were determined under LED illumination at $375 \mathrm{~nm}$ with $10 \mathrm{mg}$ of catalyst in a solution of $1.7 \mathrm{mM}$ $\mathrm{AgNO}_{3}$.
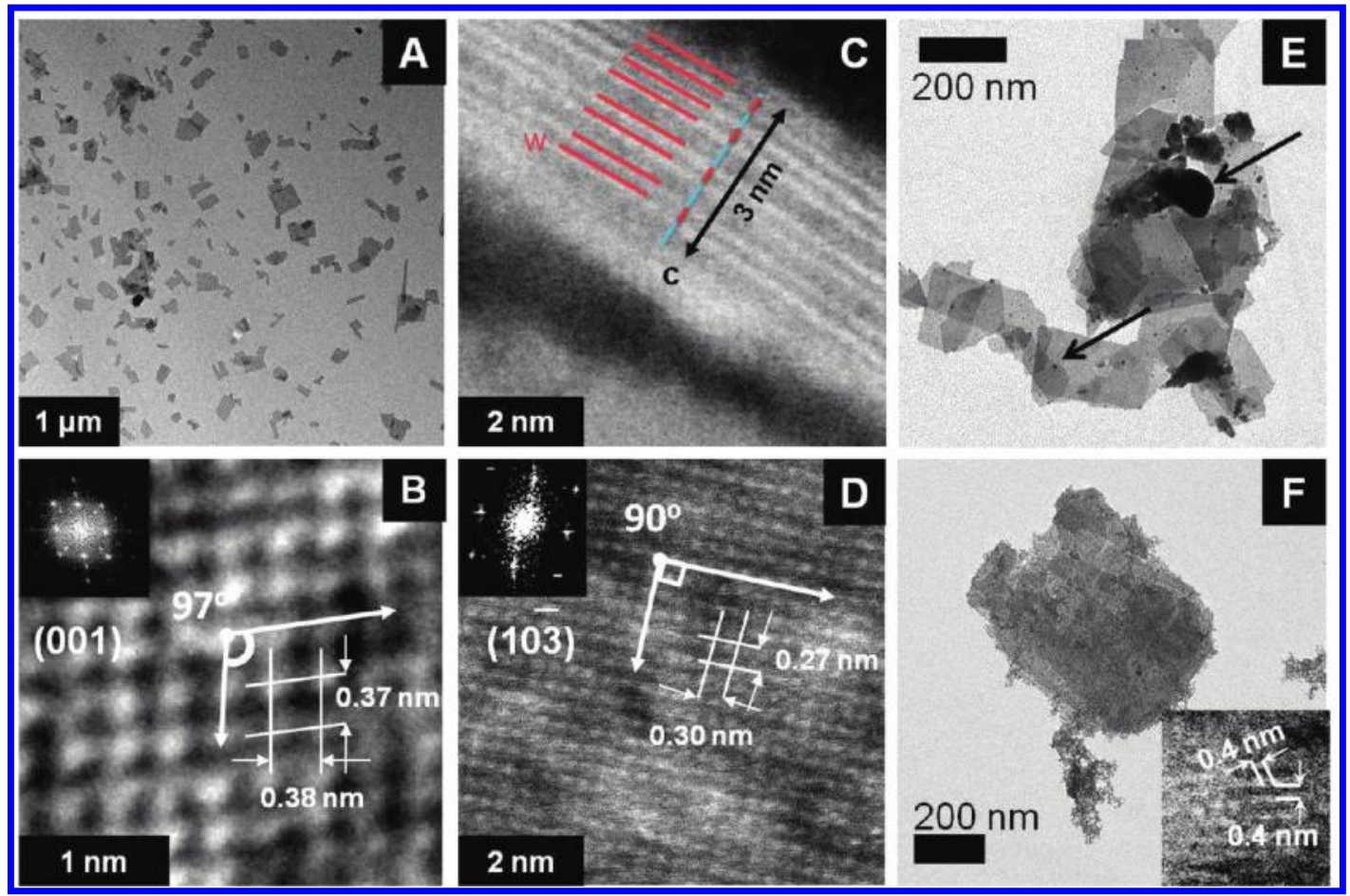

Figure 3. HR-TEM and HAADF-STEM images of nano- $\mathrm{WO}_{3}(\mathrm{~A}, \mathrm{~B})$ after exfoliation and $\mathrm{Bi}_{2} \mathrm{~W}_{2} \mathrm{O}_{9}(\mathrm{C}, \mathrm{D})$ during exfoliation. Comparison of the observed lattice in images $\mathrm{B}$ and $\mathrm{D}$ reveals that a change from tetragonal in $\mathrm{Bi}_{2} \mathrm{~W}_{2} \mathrm{O}_{9}$ (D) to monoclinic in nano-WO $\mathrm{W}_{3}(\mathrm{~B})$ has occurred. $\mathrm{HR}-\mathrm{TEM}$ image (C) depicts a partially exfoliated $\mathrm{Bi}_{2} \mathrm{~W}_{2} \mathrm{O}_{9}$ crystal from the side, revealing $\mathrm{WO}_{3}$ layers (indicated with red lines) separated by darker regions of partially removed $\mathrm{Bi}_{2} \mathrm{O}_{2}{ }^{2+}$. Nano- $\mathrm{WO}_{3}(\mathrm{E})$ after a $5 \mathrm{~h}$ irradiation in $8.3 \mathrm{mM} \mathrm{AgNO}_{3}$ (photodeposited $\mathrm{Ag}^{0}$ is indicated with arrows) and nano-WO (F) after a $5 \mathrm{~h}$ irradiation $(>400 \mathrm{~nm})$ in $8.3 \mathrm{mM}\left(\mathrm{NH}_{4}\right)_{2} \mathrm{Ce}\left(\mathrm{NO}_{3}\right)_{6}$. Inset: HR-TEM image of secondary $\mathrm{WO}_{3}$ nanocrystal formed by Ostwald ripening.

The structure change is likely driven by an increase in packing density of $\mathrm{W}$ and $\mathrm{O}$ atoms. It appears to require basic conditions that are present during treatment with $\mathrm{TMA}(\mathrm{OH}) / \mathrm{TBA}(\mathrm{OH})$, since acid treatment of $\mathrm{Bi}_{2} \mathrm{~W}_{2} \mathrm{O}_{9}$ alone is known to preserve the tetragonal structure of the $\mathrm{H}_{2} \mathrm{~W}_{2} \mathrm{O}_{7}$ layers. ${ }^{16} \mathrm{~A}$ full structure conversion to monoclinic $\mathrm{WO}_{3}$ can be achieved by removing the nanosheets from solution, and drying them under elevated temperature $\left(90^{\circ} \mathrm{C}\right)$. Such samples show the $\mathrm{X}$-ray diffraction pattern typical of monoclinic $\mathrm{WO}_{3}$ (top of Figure 4, JCPDS 43-1035). Like the structure distortion above, this transformation leads to a reduction of surface energy, and an increase in packing density, which allows for greater lattice enthalpy.

Figure 5 compares diffuse reflectance optical spectra of nano$\mathrm{WO}_{3}$ with those of bulk- $\mathrm{WO}_{3}$ and of $\mathrm{Bi}_{2} \mathrm{~W}_{2} \mathrm{O}_{9}$. The spectra are represented as the Kubelka-Munk function to reduce the scattering contribution from the powders. It can be seen that $\mathrm{Bi}_{2} \mathrm{~W}_{2} \mathrm{O}_{9}(2.81 \mathrm{eV})$ has an increased band gap compared to bulk- $\mathrm{WO}_{3}(2.68 \mathrm{eV})$. The increase in band gap has to be at least partially attributed to quantum size confinement of the $\mathrm{W}_{2} \mathrm{O}_{6}$ layers in $\mathrm{Bi}_{2} \mathrm{~W}_{2} \mathrm{O}_{9}$. The layers are only $0.75 \mathrm{~nm}$ thick, below the Bohr exciton radius of metal oxide particles (e.g., for $\left.\mathrm{TiO}_{2}, r_{\mathrm{B}}=0.75-1.9 \mathrm{~nm}\right) .{ }^{17}$ Upon exfoliation to nano- $\mathrm{WO}_{3}$, the band gap increases further to $2.88 \mathrm{eV}$. This is probably a result of the structure change to monoclinic, which allows for a less strained, more stable coordination environment around W. As a consequence, the HOMO-LUMO gap is expected to increase.

Surface photovoltage spectroscopy is a useful tool to probe generation and separation of charge carriers in semiconductor 


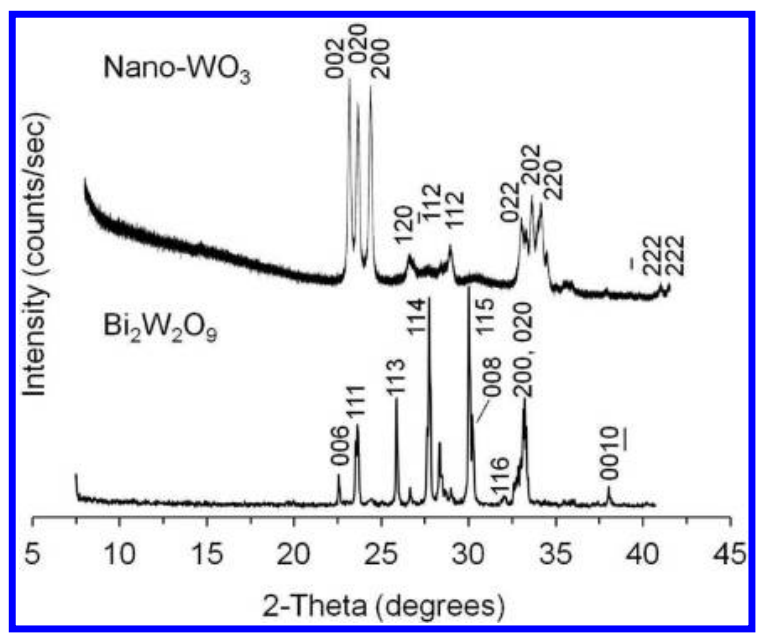

Figure 4. Powder X-ray diffraction (XRD) spectra of nano- $\mathrm{WO}_{3}$ and the parent material $\mathrm{Bi}_{2} \mathrm{~W}_{2} \mathrm{O}_{9}$ (JCPDS No. 089-8114). nano$\mathrm{WO}_{3}$ is consistent with that of monoclinic $\mathrm{WO}_{3}$ (JCPDS No. 43-1035).

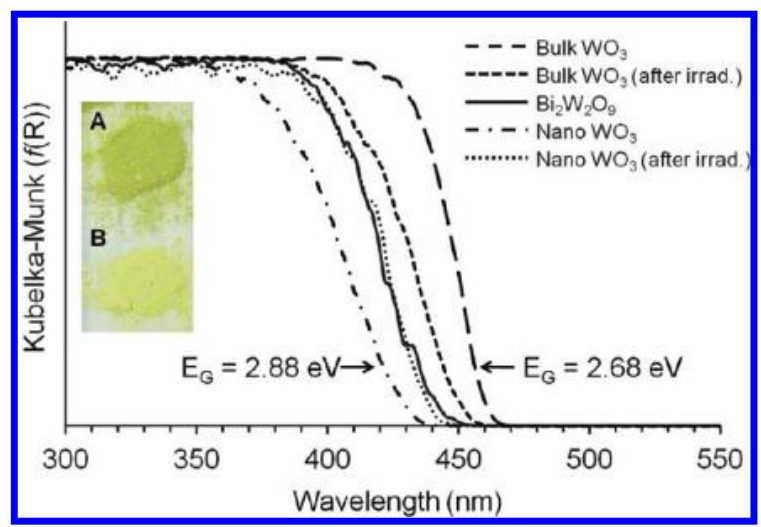

Figure 5. Diffuse reflectance spectra of bulk- $\mathrm{WO}_{3}$ before and after visible $(>400 \mathrm{~nm})$ light irradiation for $22 \mathrm{~h}$ in a $44 \mathrm{mM}$ $\left(\mathrm{NH}_{4}\right)_{2} \mathrm{Ce}\left(\mathrm{NO}_{3}\right)_{6}$ solution. Spectra of the parent material $\mathrm{Bi}_{2} \mathrm{~W}_{2} \mathrm{O}_{9}$ and exfoliated nano- $\mathrm{WO}_{3}$ before and after visible light irradiation for 5 $\mathrm{h}$ in a $21 \mathrm{mM}\left(\mathrm{NH}_{4}\right)_{2} \mathrm{Ce}\left(\mathrm{NO}_{3}\right)_{6}$ solution. Inset: Photographs of bulk$\mathrm{WO}_{3}$ (A) before and (B) after irradiation.

nanoparticles. ${ }^{12,18-20}$ Here, a nanocrystal film of nano- $\mathrm{WO}_{3}$ was first deposited on gold or $\mathrm{F}: \mathrm{SnO}_{2}$ substrate and placed into a vacuum chamber at $2 \times 10^{-4} \mathrm{mBar}$. A vibrating gold Kelvin probe is then used to measure the contact potential difference (CPD) of the sample versus the gold reference. In the dark the CPD values are determined mainly by the difference of workfunctions between the sample and the reference probe. Under band gap illumination, photogenerated charge carriers change the CPD value. This is shown in Figure 6 as a function of illumination energy. A negative change of the $\mathrm{CPD}$ value occurs as the photon energy approaches the band gap of the material. The negative sign of $\triangle \mathrm{CPD}$ indicates that photogenerated electrons are preferentially separated toward the FTO substrate, leaving the $\mathrm{WO}_{3}$ surface increasingly positively charged. The $\triangle \mathrm{CPD}$ value reaches its maximum value of $-0.360 \mathrm{~V}$ at $3.5 \mathrm{eV}$. This demonstrates that nano- $\mathrm{WO}_{3}$ is able to generate and separate electron-hole pairs under band gap excitation. The CPD signal of a fresh $\mathrm{WO}_{3}$ film under repeated illumination is shown in Figure 6B. Initial exposure of the film to $50 \mathrm{~s}$ of $400 \mathrm{~nm}$ light leads to a $0.25 \mathrm{~V}$ drop in CPD. During the following $500 \mathrm{~s}$ dark period, the signal recovers only partially $(35 \mathrm{mV})$, and subsequent illumination/dark cycles result in increasingly smaller $\triangle \mathrm{CPD}$ signals. This indicates that the positive charges on the $\mathrm{WO}_{3}$ film are located in deep trap sites that are not in thermal equilibrium with the FTO substrate. We tentatively identify these sites as the redox sites for water oxidation.

To evaluate the ability of the $\mathrm{WO}_{3}$ nanosheets to photooxidize water, samples of nano- and bulk- $\mathrm{WO}_{3}$ were suspended in aqueous $\mathrm{AgNO}_{3}$ or $\left(\mathrm{NH}_{4}\right)_{2} \mathrm{Ce}\left(\mathrm{NO}_{3}\right)_{6}$ and illuminated with a $300 \mathrm{~W}$ Xe arc lamp using its full $(>250 \mathrm{~nm})$ or filtered $(>400 \mathrm{~nm})$ spectrum. Experiments were carried out with limiting concentrations of sacrificial agents to avoid complications due to precipitation of the catalysts caused by high ionic strength and low $\mathrm{pH}$. The results of these experiments are shown in Table 1 and Figure 7. It can be seen that the highest $\mathrm{O}_{2}$ evolution rates $\left(69.7 \mu \mathrm{mol} \mathrm{h}^{-1}\right.$ for bulk and $35.5 \mu \mathrm{mol} \mathrm{h}^{-1}$ for nano- $\mathrm{WO}_{3}$ ) are observed under $>250$ illumination in the presence of $8.3 \mathrm{mM} \mathrm{Ag}^{+}$(Figure $7 \mathrm{~A}$ ). After $5 \mathrm{~h}$ of irradiation, 100 and $59 \%$ of the possible total amount of $\mathrm{O}_{2}$ have been evolved by bulk- and nano- $\mathrm{WO}_{3}$, respectively. Under visible light $(>400 \mathrm{~nm})$, both materials are considerably less active (Figure $7 \mathrm{~B}$ ). Here, bulk- and nano- $\mathrm{WO}_{3}$ support rates of 39.8 $\mu \mathrm{mol} \mathrm{h} \mathrm{h}^{-1}$ and $5.2 \mu \mathrm{mol} \mathrm{h}{ }^{-1}$ (with $50 \mathrm{~mL}$ of $8.3 \mathrm{mM} \mathrm{Ag}^{+}$) respectively, which is about 1.8 (bulk) and 6.8 (nano) times less

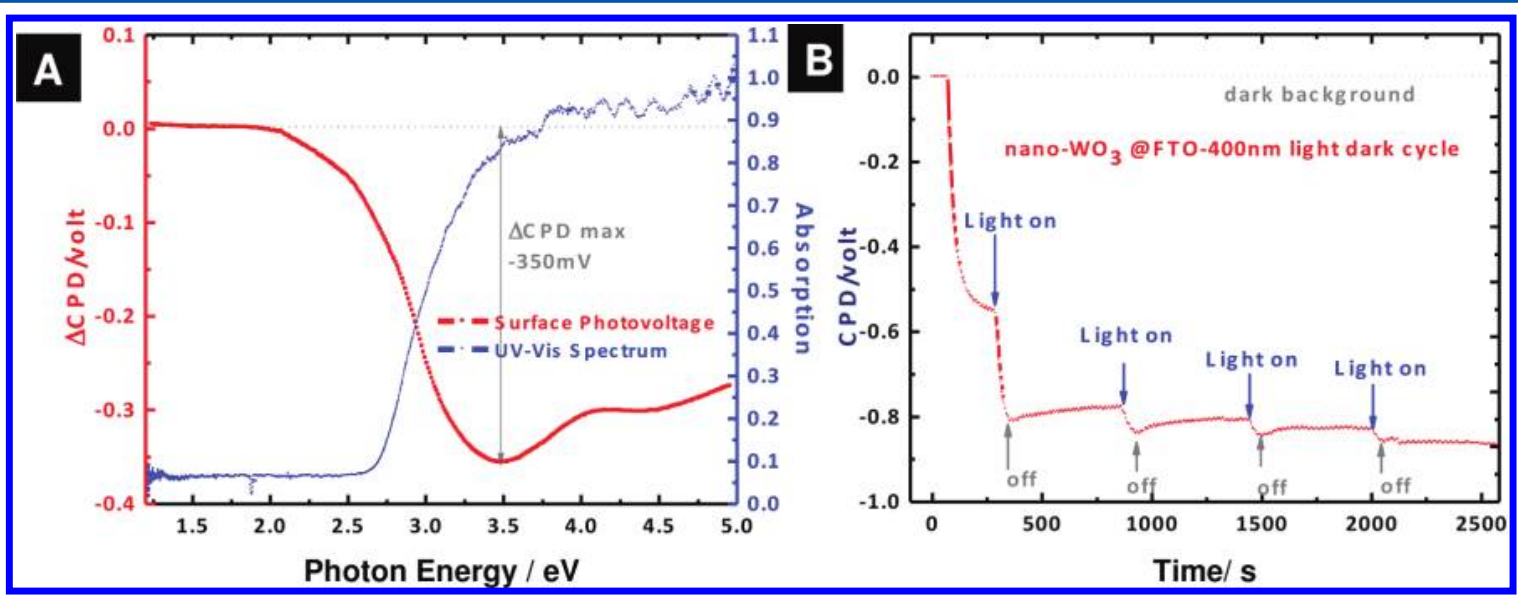

Figure 6. (A) Light-induced contact potential change $\triangle \mathrm{CPD}$ (left axis) and absorption spectrum (right axis) of nano- $\mathrm{WO}_{3}$ film on F:SnO 2 (FTO) electrode in vacuum $\left(2 \times 10^{-4} \mathrm{mbar}\right)$ versus excitation energy. (B) $\Delta \mathrm{CPD}$ signal for nano- $\mathrm{WO}_{3}$ film on FTO substrate under repeated illumination at $400 \mathrm{~nm}$. 


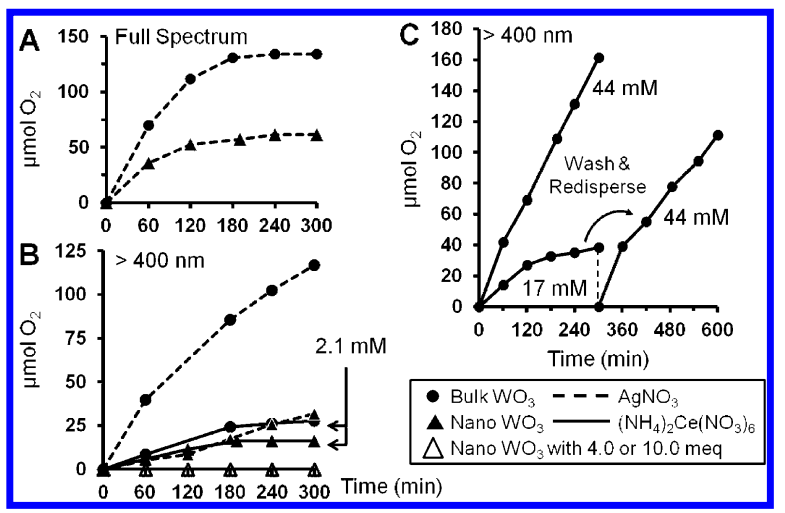

Figure 7. Oxygen evolution data under (A) full spectrum $(>250 \mathrm{~nm})$ irradiation and under (B) visible only $(>400 \mathrm{~nm})$ irradiation. Experiments were carried out in degassed/deionized water in the presence of $50 \mathrm{~mL}$ of $8.3 \mathrm{mM}$ sacrificial electron acceptor (unless other indicated). (C) Comparison of oxygen evolution from visible irradiation of bulk- $\mathrm{WO}_{3}$ for a single irradiation versus two sequential irradiations, which included washing and redispersion of the catalyst in new sacrificial acceptor solution.

than that under $>250 \mathrm{~nm}$ irradiation. After $5 \mathrm{~h}$ of irradiation, $100 \%$ of the total possible $\mathrm{O}_{2}$ (based on $415 \mu \mathrm{mol} \mathrm{AgNO}_{3}$ ) was produced by bulk- $\mathrm{WO}_{3}$. For nano- $\mathrm{WO}_{3}, 31 \%$ of all sacrificial reagent is consumed based on an observed total of $31.8 \mu \mathrm{mol} \mathrm{O}$. To avoid complications from silver deposition, we repeated irradiations for the tungsten oxides with ammonium cerium nitrate. Because of UV instability, $\mathrm{Ce}^{4+}$ could only be used for visible light experiments. Interestingly, no $\mathrm{O}_{2}$ was evolved from nano- $\mathrm{WO}_{3}$ when $8.3 \mathrm{mM}$ or $21 \mathrm{mM}$ of $\mathrm{Ce}^{4+}$ were present (approximately 2 and 5 meq., respectively). However, with $2.1 \mathrm{mM} \mathrm{Ce}^{4+}$, we observed $\mathrm{O}_{2}$ formation at an initial rate of $5.9 \mu \mathrm{mol} \mathrm{h}{ }^{-1}$, somewhat above that with $\mathrm{Ag}^{+}\left(5.2 \mu \mathrm{mol} \mathrm{h}{ }^{-1}\right)$. After $5 \mathrm{~h}$, a total of $16.1 \mu \mathrm{mol}$ of $\mathrm{O}_{2}$ has evolved, corresponding to a $61 \%$ consumption of the sacrificial donor. These results indicate that $\mathrm{Ce}^{4+}$ is not as good as silver in driving photochemical water oxidation. Summarizing these tests nano- $\mathrm{WO}_{3}$ is not as efficient for photochemical $\mathrm{O}_{2}$ production as bulk- $\mathrm{WO}_{3}$. As the right column in Table 1 shows, neither bulknor nano- $\mathrm{WO}_{3}$ reach a turnover number greater than unity. However, the picture changes when the experiments are repeated with $\mathrm{Ag}^{+}$under monochromatic irradiation at $375 \mathrm{~nm}$. Here, bulk$\mathrm{WO}_{3}$ reaches an initial $\mathrm{O}_{2}$ evolution rate of $2.5 \mu \mathrm{mol} \mathrm{h}{ }^{-1}$, compared to $3.2 \mu \mathrm{mol} \mathrm{h}{ }^{-1}$ for nano- $\mathrm{WO}_{3}$. Within the first hour, the apparent quantum efficiencies are $1.43 \%$ for bulk and $1.55 \%$ for the nanomaterial. These results indicate that nano- $\mathrm{WO}_{3}$ is slightly more active than bulk- $\mathrm{WO}_{3}$ and that the lesser performance of nano- $\mathrm{WO}_{3}$ under Xe-light is due to its lower light absorption cross-section, caused by the larger band gap of $2.88 \mathrm{eV}$, compared to $2.68 \mathrm{eV}$ for the bulk (Figure 5).

Over the course of the irradiations, the materials undergo several changes, which are responsible for the loss of $\mathrm{O}_{2}$ activity over time. As the TEM for irradiated nano- $\mathrm{WO}_{3}$ (Figure 3E) shows, photochemical oxygen evolution in the presence of $\mathrm{AgNO}_{3}$ is accompanied by the formation of silver particles on the nano- $\mathrm{WO}_{3}$ and in solution. The silver particles compete for photons and cover up redox active sites on $\mathrm{WO}_{3}$, rendering the material less active. At the same time, water oxidation leads to release of protons and a decrease of the solution $\mathrm{pH}$. During a typical $5 \mathrm{~h}$ irradiation (in $8.3 \mathrm{mM} \mathrm{AgNO}_{3}$ ) the $\mathrm{pH}$ falls from an initial value of $\sim 4.9$ to a final value of $\sim 2.0$ for bulk- $\mathrm{WO}_{3}$ and from 6.5 to 2.6 for nano- $\mathrm{WO}_{3}$ (Table 1). This leads to aggregation of nano- $\mathrm{WO}_{3}$ (Figure $3 \mathrm{E}$ ), as the $\mathrm{pH}$ approaches the point of zero charge of the material. The aggregation problems are more severe with $\left(\mathrm{NH}_{4}\right)_{2} \mathrm{Ce}\left(\mathrm{NO}_{3}\right)_{6}$ because of the acidity of ammonium ion.

Lastly, we note that irradiation with the $\mathrm{Ce}^{4+}$ salt does also lead to changes in the $\mathrm{WO}_{3}$ materials. For postirradiated nano$\mathrm{WO}_{3}$, a red shift of the absorption edge from 430 to $440 \mathrm{~nm}$ is evident in the optical spectra (Figure 5). Inspection of the irradiated nano- $\mathrm{WO}_{3}$ by TEM reveals $\sim 5 \mathrm{~nm}$ nanoparticles near the original $\mathrm{WO}_{3}$ nanosheets (Figure 3F). HR-TEM images (inset in Figure 3F) confirm that these particles are crystalline and energy dispersive spectroscopy indicates high amounts of tungsten and low amounts of cerium present on both the particulate matter surface and the original nano- $\mathrm{WO}_{3}$ after irradiation in $\left(\mathrm{NH}_{4}\right)_{2} \mathrm{Ce}\left(\mathrm{NO}_{3}\right)_{6}$ solution. We hypothesize that irradiation in the presence of $\mathrm{Ce}^{4+}$ salt promotes recrystallization of the nanosheets to form $\mathrm{WO}_{3}$ nanodots with lower surface area (Ostwald ripening), and increased diameter ( $5 \mathrm{~nm}$ instead of $0.75 \mathrm{~nm}$ for the nanosheets). This size increase explains the red shift in the spectrum upon irradiation. The transformation of nano- $\mathrm{WO}_{3}$ is facilitated by the ammonium ions in $\left(\mathrm{NH}_{4}\right)_{2} \mathrm{Ce}\left(\mathrm{NO}_{3}\right)_{6}$ and likely involves the tungstate $\left(\mathrm{WO}_{4}{ }^{2-}\right)^{22}$ and para tungstate $\left(\mathrm{W}_{12} \mathrm{O}_{42}{ }^{4-}\right)$ ions. This side reaction is the likely cause for the low photocatalytic activity in the presence of $\left(\mathrm{NH}_{4}\right)_{2} \mathrm{Ce}\left(\mathrm{NO}_{3}\right)_{6}$.

Opposite to nano- $\mathrm{WO}_{3}$, irradiation of bulk- $\mathrm{WO}_{3}$ in the presence of the $\mathrm{Ce}^{4+}$ salt causes a small blue shift of the absorption spectrum from 462 to $453 \mathrm{~nm}(2.74 \mathrm{eV})$, and a concomitant change of the color from green to yellow (inset in Figure 5). These optical changes are related to the disappearance of surface impurities (reduced $\mathrm{W}$ ions) in the initial material. ${ }^{23}$ The removal of these sites does not degrade the catalytic performance of the material. As Figure 7C shows, any loss of $\mathrm{O}_{2}$ activity upon irradiation with $17 \mathrm{mM} \mathrm{Ce}{ }^{4+}$ is temporary, and can be restored upon washing the material and redispersing it in a fresh solution of $50 \mathrm{~mL}$ of $44 \mathrm{mM} \mathrm{Ce}^{4+}$.

In order to investigate the kinetics of water oxidation with both types of $\mathrm{WO}_{3}$, electrochemical scans on films of the materials were performed in the dark using $0.1 \mathrm{M} \mathrm{H}_{2} \mathrm{SO}_{4}$ as electrolyte (Figure 8). Under these conditions, both nano- and bulk- $\mathrm{WO}_{3}$ are found to oxidize water at $+2.19 \mathrm{~V}$ (NHE, $\mathrm{pH} 1$, $1.0 \mathrm{~mA} \mathrm{~cm}{ }^{-2}$ ), which is slightly improved over what Hodes et al. reported for $\mathrm{WO}_{3}$ films in $1976\left(2.2 \mathrm{~V}\right.$ at $0.2 \mathrm{~mA} \mathrm{~cm}{ }^{-2}$, note the lower current density). ${ }^{1}$ These electrochemical overpotentials for water oxidation are exceptionally high (nearly $1.0 \mathrm{~V}$ ) in comparison to other materials, and may be viewed as a limiting factor in the use of $\mathrm{WO}_{3}$ as a photoanode material.

Under illumination, small photocurrents $\left(<1 \mu \mathrm{A} \mathrm{cm}^{-2}\right)$ can be observed for both nano- and bulk- $\mathrm{WO}_{3}$. The small size of the current is due to the low quality of the films and bad electrical contact with the electrode. Photocurrent onsets are observed at potentials above $+0.23 \mathrm{~V}$ for nano- $\mathrm{WO}_{3}$, and $+0.11 \mathrm{~V}$ for bulk- $\mathrm{WO}_{3}$. These values can be taken to approximate the conduction band edge of $\mathrm{WO}_{3}$. Considering that flatband potentials depend strongly on material preparation and $\mathrm{pH}^{24}$ the values compare favorably with the literature $(0.33-0.6 \mathrm{~V}$ for $\mathrm{WO}_{3}$ at $\mathrm{pH} 0,{ }^{1,25}$ and $0.20-0.25 \mathrm{~V}^{24,26}$ at $\left.\mathrm{pH} 2-4.68\right)$.

The photocurrent onset potentials and the optical band gap data can be used to construct the energy diagram in Figure 9. The diagram shows that the energetics of both materials are similar, except that the conduction and valence band edges of nano- $\mathrm{WO}_{3}$ are shifted to more oxidizing potentials and that its band gap is slightly larger $(2.88 \mathrm{eV}$ instead of $2.74 \mathrm{eV})$. For both materials, oxidation of water and reduction of silver ion are 


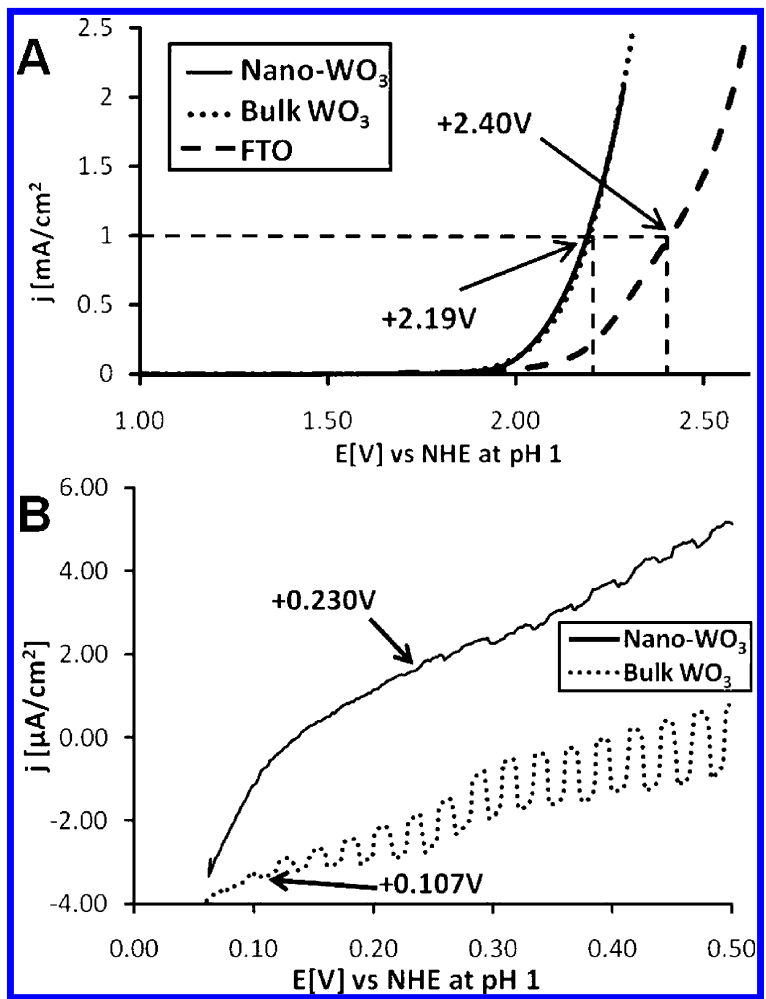

Figure 8. Electrochemical data for bulk- and nano- $\mathrm{WO}_{3}$ films dropcoated onto FTO electrodes in $0.1 \mathrm{M} \mathrm{H}_{2} \mathrm{SO}_{4}$ solution. (A) Voltammetric traces $\left(10 \mathrm{mV} \mathrm{s}^{-1}\right)$, and (B) photocurrent spectra $\left(10 \mathrm{mV} \mathrm{s}^{-1}\right)$ under chopped irradiation $(>250 \mathrm{~nm})$. Potentials are reported against normal hydrogen electrode (NHE).

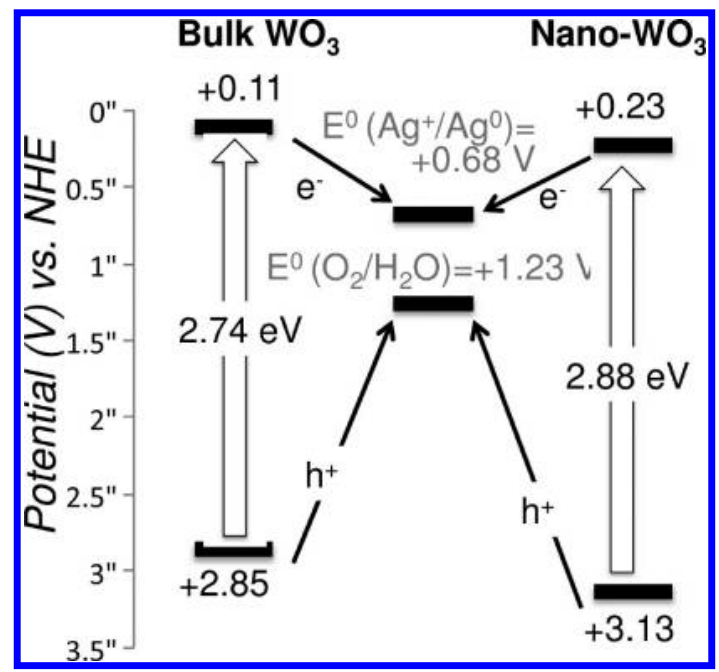

Figure 9. Energy diagram for photochemical water oxidation at $\mathrm{pH} 0$ with bulk- and nano- $\mathrm{WO}_{3}$. The $\mathrm{Ag}^{+} / \mathrm{Ag}$ potential is for a $10 \mathrm{mM}$ solution.

thermodynamically favorable. Significant energy loss $(1.6-1.9 \mathrm{eV})$ occurs during hole transfer from the $\mathrm{WO}_{3}$ valence band to water. However, approximating the oxidation barrier with the dark water oxidation overpotential (1.0 V, Figure $8 \mathrm{~A})$, this expense may be necessary to drive the reaction. The diagram also shows that both systems are theoretically capable of net conversion of photochemical into chemical energy (about $1.23-0.68 \mathrm{eV}=0.55 \mathrm{eV}$ per photon), if one would increase the quantum efficiency of presently $1.5 \%$ to about unity.

\section{CONCLUSION}

In summary, we have demonstrated that the principle photophysical and photochemical properties of $\mathrm{WO}_{3}$ are maintained in subnanometer thick single-crystal $\mathrm{WO}_{3}$ nanosheets, and that the photochemical water oxidation efficiency of nano- $\mathrm{WO}_{3}$ is comparable to that of the bulk form. Because of quantum size confinement, a blue shift of the photoresponse occurs in the nanomaterial. The principle limitations of nano$\mathrm{WO}_{3}$ for water oxidation arise from the use of silver ion as the electron acceptor (leads to silver deposits) and from the tendency of the nanosheets to aggregate (in the solid state) or recrystallize (Ostwald ripening) when in contact with solutions of ammonium cerium nitrate.

\section{AUTHOR INFORMATION}

\section{Corresponding Author}

*E-mail: fosterloh@ucdavis.edu. Fax: (+1)530 7528995.

\section{ACKNOWLEDGMENTS}

F.E.O. thanks Thomas Dittrich (Helmholtz Center Berlin for Materials and Energy) for the introduction to surface photovoltage spectroscopy and for helpful discussions. M.R.W. thanks A.J.M. T.K.T. thanks NSF for a Graduate Research Fellowship 2011. Financial support was provided by Research Corporation for Science Advancement (Scialog award), by the National Science Foundation (NSF, Grants 0829142 and 1133099) and by the U.S. Department of Energy under Grant FG02-03ER46057.

\section{REFERENCES}

(1) Hodes, G.; Cahen, D.; Manassen, J. Nature 1976, 260, 312.

(2) Hardee, K. L.; Bard, A. J. I. Electrochem. Soc. 1977, 124, 215.

(3) Darwent, J. R.; Mills, A. J. Chem. Soc., Faraday Trans. II 1982, $78,359$.

(4) Wang, H. L.; Deutsch, T.; Turner, J. A. J. Electrochem. Soc. 2008, 155, F91.

(5) Sasaki, Y.; Nemoto, H.; Saito, K.; Kudo, A. J. Phys. Chem. C 2009, 113, 17536.

(6) Kato, H.; Sasaki, Y.; Wase, A.; Kudo, A. B. Chem. Soc. Jpn. 2007, $80,2457$.

(7) Abe, R.; Takata, T.; Sugihara, H.; Domen, K. Chem. Commun. 2005, 30, 3829.

(8) Higashi, M.; Abe, R.; Teramura, K.; Takata, T.; Ohtani, B.; Domen, K. Chem. Phvs. Lett. 2008, 452, 120.

(9) Maeda, K.; Higashi, M.; Lu, D. L.; Abe, R.; Domen, K. J. Am. Chem. Soc. 2010, 132, 5858.

(10) Higashi, M.; Abe, R.; Takata, T.; Domen, K. Chem. Mater. 2009, 21, 1543.

(11) Townsend, T. K.; Sabio, E. M.; Browning, N. D.; Osterloh, F. E. Enerov Environ. Sci. 2011, 4, 4270.

(12) Frame, F. A.; Townsend, T. K.; Chamousis, R. L.; Sabio, E. M.; Dittrich, T.; Browning, N. D.; Osterloh, F. E. J. Am. Chem. Soc. 2011, 133, 7264.

(13) Tanaka, D.; Oaki, Y.; Imai, H. Chem. Commun. 2010, 46, 5286.

(14) Schaak, R. E.; Mallouk, T. E. Chem. Commun. 2002, 7, 706.

(15) Loopstra, B. O.; Boldrini, P. Acta Crystallogr. 1966, 21, 158.

(16) Kudo, M.; Ohkawa, H.; Sugimoto, W.; Kumada, N.; Liu, Z.; Terasaki, O.; Sugahara, Y. Inorg. Chem. 2003, 42, 4479.

(17) Sant, P. A.; Kamat, P. V. Phvs. Chem. Chem. Phys. 2002, 4, 198.

(18) Gross, D.; Mora-SeroÌ, I. n.; Dittrich, T.; Belaidi, A.; Mauser, C.; Houtepen, A. J.; Como, E. D.; Rogach, A. L.; Feldmann, J. J. Am. Chem. Soc. 2010, 132, 5981.

(19) Mora-Sero, I.; Bisquert, J.; Dittrich, T.; Belaidi, A.; Susha, A. S.; Rogach, A. L. I. Phys. Chem. C 2007, 111, 14889. 
(20) Beranek, R.; Neumann, B.; Sakthivel, S.; Janczarek, M.; Dittrich, T.; Tributsch, H.; Kisch, H. Chem. Phvs. 2007, 339, 11.

(21) Kudo, A.; Hijii, S. Chem. Lett. 1999, 28, 1103.

(22) Lillard, R. S.; Kanner, G. S.; Butt, D. P. J. Electrochem. Soc. 1998, $145,2718$.

(23) Chatten, R.; Chadwick, A. V.; Rougier, A.; Lindan, P. J. D. J. Phys. Chem. B 2005, 109, 3146.

(24) Diquarto, F.; Dipaola, A.; Sunseri, C. Electrochim. Acta 1981, 26, 1177.

(25) Leland, J. K.; Bard, A. J. I. Phys. Chem. 1987, 91, 5083.

(26) Wang, H. L.; Lindgren, T.; He, J. J.; Hagfeldt, A.; Lindquist, S. E. I. Phvs. Chem. B 2000, 104, 5686. 